\title{
Spatial and Temporal Heterogeneity Creates a "Brown Tide" in Root Phenology and Nutrition
}

\author{
Sean C. P. Coogan, ${ }^{1}$ Scott E. Nielsen, ${ }^{1}$ and Gordon B. Stenhouse ${ }^{2}$ \\ ${ }^{1}$ Department of Renewable Resources, University of Alberta, 751 General Services Building, Edmonton, AB, Canada T6G $2 \mathrm{H1}$ \\ ${ }^{2}$ Grizzly Bear Program, Foothills Research Institute, 1176 Switzer Drive, Hinton, AB, Canada T7V 1 X6
}

Correspondence should be addressed to Sean C. P. Coogan, scoogan@ualberta.ca

Received 13 April 2012; Accepted 26 May 2012

Academic Editors: R. B. Boone and P. Ferrandis

Copyright ( 92012 Sean C. P. Coogan et al. This is an open access article distributed under the Creative Commons Attribution License, which permits unrestricted use, distribution, and reproduction in any medium, provided the original work is properly cited.

\begin{abstract}
Spatial and temporal heterogeneity in plant phenology and nutrition benefits herbivores by prolonging the period in which they can forage on nutritious plants. Landscape heterogeneity can therefore enhance population performance of herbivores and may be a critically important feature of their habitat. The benefits of resource heterogeneity over space and time should extend not only to large herbivores using above-ground vegetation but also to omnivores that utilize below-ground resources. We used generalized linear models to evaluate whether spatial heterogeneity influenced temporal variation in the crude protein content of alpine sweetvetch (Hedysarum alpinum) roots in west-central Alberta, Canada, thereby potentially offering nutritional benefits to grizzly bears (Ursus arctos). We demonstrated that temporal patterns in the crude protein content of alpine sweetvetch roots were influenced by spatial heterogeneity in annual growing season temperatures and soil moisture and nutrients. Spatial heterogeneity and asynchrony in the protein content of alpine sweetvetch roots likely benefit grizzly bears by prolonging the period they can forage on high quality resources. Therefore, we have presented evidence of what we termed a "brown wave" or "brown tide" in the phenology and nutrition of a below-ground plant resource, which is analogous to the previously described "green wave" in above-ground resources.
\end{abstract}

\section{Introduction}

A central challenge in ecology lies in understanding the ways in which spatiotemporal variation in resources shape the biotic environment. While consumable above-ground net primary production limits the ability of a landscape to support herbivores $[1,2]$, this limitation may be altered by the timing and spatial patterns of plant growth. This is especially true for spatial heterogeneity that causes temporal variation in plant phenology (e.g., budburst, flowering, and fruiting), because it provides nutritional benefits to herbivores by prolonging the period they can forage on highly nutritious immature plants [3]. Thus, variable landscapes increase the ability of herbivores to access highly nutritious plants by reducing spatial and temporal autocorrelation in plant growth [4]. Without the influence of spatial heterogeneity on plant phenology, plant growth would be synchronized, thereby reducing the time period during which animals could consume the most nutritious plants [5]. Access to landscape heterogeneity can therefore enhance population performance of herbivores and may be a critically important feature of their habitat $[4,6,7]$.

Many relationships between time, plant phenology, and animal foraging have been established. For example, during springtime when green vegetation is immature, plants have higher protein and lower fibre content than during the summer when plants are maturing $[8,9]$. Migratory geese have been shown to follow this "green wave" of nutritious spring growth as they travel from temperate areas to their Arctic breeding grounds [10-12]. This "surfing" of the green wave across space and time is also common to other migratory animals including insectivorous passerine birds [13] and large herbivores such as wildebeest (Connochaetes taurinus) [14].

Regional spatial heterogeneity in phenology can also be important to animal populations, because variation in a wide 
range of abiotic factors (e.g., soil moisture and nutrients, sunlight, temperature, precipitation, topography, snow accumulation) can cause plants at different locations to initiate growth at different times. For instance, in the Serengeti plains of Africa, the population viability of Thompson's gazelle (Eudorcas thomsonii) was directly influenced by access to patches of grassland that varied in phenology as a result of spatial heterogeneity in topography, soils, and rainfall [6]. Likewise, habitats with greater spatial heterogeneity in the normalized difference vegetation index may have higher ungulate carrying capacities [15]. Heterogeneity in elevation has also been linked to the population growth of ungulates in both North America and Europe [16], and many animals shift their distribution along altitudinal gradients in response to plant phenology. For example, several deer species, including roe deer (Capreolus capreolus) [17], red deer (Cervus elaphus) [18], sika deer (Cervus Nippon) [19], and reindeer (Rangifer tarandus) [20], migrate along elevation gradients to access newly emergent, high quality forage.

Studies of spatial and temporal herbivory patterns have necessitated that researchers focus primarily on aboveground plant growth; roots are also an important food resource for many animals including omnivorous species [21-25]. Yet, despite the importance of root resources to several wildlife species, relatively little is known about root phenology and nutrition [26] despite that root production accounts for $50-90 \%$ of the primary production in temperate vegetation $[27,28]$. In west-central Alberta, Canada, roots of alpine sweetvetch (Hedysarum alpinum) are an important seasonal food for grizzly bears (Ursus arctos) [25]. The nutritional quality of alpine sweetvetch roots vary temporally dependent on plant phenology; the protein content and digestibility of sweetvetch roots is highest preflowering and postseed development $[29,30]$. This pattern is common for many short-stature perennial plants, where above-ground spring vegetation is dependent on resources that have been translocated to roots the previous fall and winter [31]. Grizzly bears respond to sweetvetch phenology and nutrition by typically consuming roots during the spring and fall when they are most nutritious $[25,29,32]$. Similar to herbivores, grizzly bears move to higher elevations and north facing slopes as spring progresses to access younger, more nutritious plants including alpine sweetvetch [29]. Considering the "green wave" phenomenon observed in herbivores, the phenological and nutritional patterns associated with alpine sweetvetch root likely provide grizzly bears with a "wave" or (given the ebb and flow in nutritional characteristics) a "tide" in below-ground resources. Similar to a "green wave," this underground or "brown wave/tide" likely prolongs the availability of nutritional roots to grizzly bears.

The objective of this paper was to test the hypothesis that spatial heterogeneity in local abiotic and biotic factors influence temporal variation in the nutritional quality of alpine sweetvetch roots, thereby potentially offering nutritional benefits to species that use the roots, such as grizzly bears. In other words, our purpose was to evaluate whether a "brown tide" in the nutritional quality of alpine sweetvetch roots exited within our study region of west-central Alberta,
Canada. In order to do this, we first describe general temtemporal poral trends in the crude protein content of alpine sweetvetch roots by plant phenophase. Then we evaluate the importance of spatial heterogeneity in crude protein content of roots using environmental variables in a geographic information system (GIS). Specifically, we hypothesized that the following five factors influence spatial and temporal patterns in crude protein content in alpine sweetvetch roots: (1) time (Julian day and year), (2) temperature (i.e., growing degree days which are influenced by elevation), (3) soil moisture and nutrients, (4) solar radiation (including slope and aspect), and (5) landcover category. We predict that, as well as observing general temporal trends and an elevation lag in phenology related to growing season temperature (i.e., interaction between time and growing degree days), crude protein content in alpine sweetvetch roots will be affected by local site factors including soils, solar radiation, and landcover category. Finally, we mapped spatial-temporal predictions of alpine sweetvetch root crude protein content over a $5,435 \mathrm{~km}^{2}$ spatial scale to examine "brown tide" patterns in our study area.

\section{Methods}

2.1. Study Area. The study area (Figure 1) is located on the eastern slopes of the Rocky Mountains and Foothills of west-central Alberta, Canada $\left(53^{\circ} 15^{\prime} \mathrm{N}, 117^{\circ} 30^{\prime} \mathrm{W}\right)$. Average summer temperatures range from $11.9^{\circ} \mathrm{C}$ in montane regions to $9.4^{\circ} \mathrm{C}$ in the subalpine, while average winter temperatures are $-7.8^{\circ} \mathrm{C}$ and $-8.9^{\circ} \mathrm{C}$, respectively [33]. Annual average rainfall in the lower elevation montane area is $464 \mathrm{~mm}$ versus $568 \mathrm{~mm}$ at the higher elevation subalpine area [33]. The foothills contain a diverse array of habitats, including black spruce (Picea mariana) and tamarack (Larix laricina) bogs; lodgepole pine (Pinus contorta) stands; open marshes; riparian areas; and mixed forests composed of lodgepole pine, aspen (Populous tremuloides), and white spruce (Picea glauca). Subalpine forests consist of spruce (Picea engelmannii $\times$ glauca), subalpine fir (Abies lasiocarpa), and lodgepole pine, with alpine meadows and rock outcrops occurring at higher elevations.

2.2. Sample Collections and Laboratory Analyses. Alpine sweetvetch taproots were collected over three years (20082010) from fourteen sites (Table 1). Five of the sites (CadMix, Cardinal, FicCon, FicMix, and Prospect) were located along a $90 \mathrm{~km}$ transect across known grizzly bear habitat. The transect was designed to observe phenological changes and growing season attributes across an elevation gradient (lower foothills, upper foothills, and subalpine habitats) by using digital time-lapse cameras as reported in Bater et al. [34]. Alpine sweetvetch roots collected at camera locations were sampled just outside of observable camera images and were selected to best represent the phenology of the site. In order to capture a wider range of environmental conditions, we also collected alpine sweetvetch roots at sites in the montane and foothills subregions outside of the transect area (Drinnan, Folding, Greg, Camp, Kinky, and Watson) 


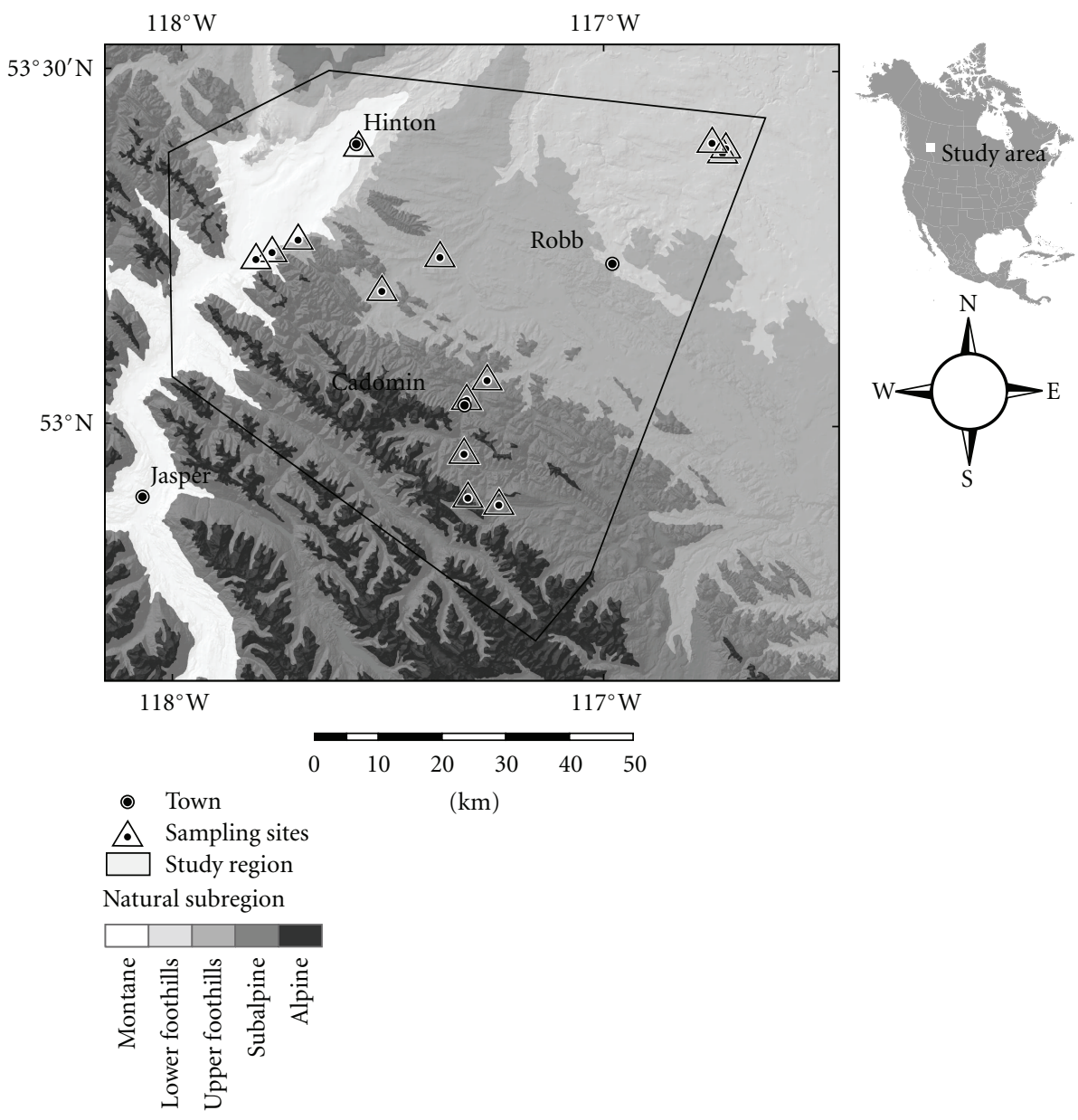

FIGURE 1: Study area depicting towns, alpine sweetvetch (Hedysarum alpinum) sampling sites, montane, lower foothills, upper foothills, subalpine, and alpine subregions. The study region outline indicates the extent of the area mapped for crude protein content predictions.

TABLE 1: Site name, coordinates, elevation (m), and natural subregion classification of Alpine sweetvetch (Hedysarum alpinum) root sampling sites from 2008-2010.

\begin{tabular}{|c|c|c|c|c|}
\hline Site name & Easting $(\mathrm{m})^{\mathrm{a}}$ & Northing $(\mathrm{m})^{\mathrm{a}}$ & Elevation $(\mathrm{m})$ & Natural subregion \\
\hline 1049 & 517,032 & $5,917,525$ & 1007 & Lower Foothills \\
\hline 1117 & 478,623 & $5,861,827$ & 2073 & Subalpine \\
\hline CadMix & 478,427 & $5,877,276$ & 1484 & Subalpine \\
\hline Cardinal & 483,439 & $5,860,769$ & 2025 & Subalpine \\
\hline Drinnan & 465,076 & $5,894,401$ & 1356 & Upper foothills \\
\hline FicCon & 518,537 & $5,916,058$ & 951 & Lower foothills \\
\hline FicMix & 519,136 & $5,916,668$ & 970 & Lower foothills \\
\hline Folding & 447,823 & $5,900,474$ & 1139 & Montane \\
\hline Greg & 474,226 & $5,899,659$ & 1246 & Upper foothills \\
\hline HTC & 461,390 & $5,916,929$ & 1036 & Montane \\
\hline Camp & 451,889 & $5,902,591$ & 1117 & Montane \\
\hline Kinky & 445,318 & $5,899,347$ & 1060 & Montane \\
\hline Prospect & 478,036 & $5,868,840$ & 1714 & Subalpine \\
\hline Watson & 481,623 & $5,880,334$ & 1468 & Upper Foothills \\
\hline
\end{tabular}

a Projection: Universal Transverse Mercator. Horizontal Datum: North American Datum 1983 (NAD83). Zone: 11 north. 
TABLE 2: Hypothesized factors, variable names, and abbreviations of variables used in candidate models.

\begin{tabular}{llr}
\hline Hypothesized factor & Variable names (predictor variables) & Abbreviation \\
\hline \multirow{2}{*}{ Temporal } & Julian day & JDAY \\
& Julian day squared (quadratic) & JDAY2 \\
& Year & YEAR \\
Soils & Terrain wetness (compound topographic index) & GEO \\
& Bedrock formation & GGD \\
Temperature & Growing degree day $\left(5^{\circ}\right.$ C) & GLBL172 \\
Slope/aspect and sunlight & Global solar radiation $($ on Julian day 172) & CROWN \\
& Crown cover & LANCOV \\
Landcover & Landcover category &
\end{tabular}

and at a grizzly bear telemetry locations with evidence of sweetvetch digging (sites 1049 and 1117). All samples were frozen following collection.

Nutritional analyses of crude protein content were performed in the Proximate Laboratories of the Department of Agriculture, Food, and Nutritional Sciences at the University of Alberta. Crude protein $(\mathrm{N} \times 6.25)$ was determined via combustion analysis using a LECO TruSpec N/C Analyzer (Leco Corporation, St. Joseph, Michigan, USA). Moisture was determined by oven drying at $110^{\circ} \mathrm{C}$ (a small number of samples were determined by oven drying at $105^{\circ} \mathrm{C}$ ). All estimates were corrected to a $100 \%$ dry matter basis.

2.3. Phenological Changes. We grouped 112 of 117 total root samples (we could not identify the phenological stage of five samples) into six phenophases (preleaf, leaf, bud, flower, seed, dormant). For each phenological stage, mean and standard error of crude protein was estimated and an ANOVA used to test for significant differences between groups (phenophases). A histogram plot of residuals and a Shapiro-Wilk test was used to assess normality, while heterogeneity of variances was assessed by examining a residual plot and a Bartlett test. Pair-wise one-way $t$-tests with adjustments (Holm's) for multiple inferences were used to test for significant differences between phenophases.

Because grizzly bears in the study area often have home ranges either primarily in (1) subalpine and alpine habitats (elevation $>1,700 \mathrm{~m}$ ) or (2) foothills and montane habitats (elevation $<1,700 \mathrm{~m}$ ) [25], we also describe the range of dates of each phenophase according to these broad elevation classes.

2.4. Spatial and Temporal Heterogeneity of Crude Protein Content in Alpine Sweetvetch Roots. To examine how spatial heterogeneity influences temporal variation in the crude protein content of alpine sweetvetch roots, we evaluated support for a series of a priori candidate models that describe both temporal and spatial heterogeneity of root crude protein content $(n=117)$. Spatial factors hypothesized to influence crude protein content in roots included soil moisture and nutrients, temperature, solar radiation, and landcover category (Table 2).
Soil moisture and nutrients were represented by both geological formation (GEO) [35] representing regional differences in parent material and for local soil conditions by the steady state terrain wetness index called the compound topographic index (CTI) derived from a $30 \mathrm{~m}$ digital elevation model (DEM) and the CTI.AML ArcInfo script from Evans [36]. CTI has been positively related to soil moisture, horizon depth, percent silt, organic matter, and phosphorous $[37,38]$ and was previously used for modelling the distribution of several grizzly bear plant foods in the study region, including alpine sweetvetch [38, 39]. Annual growing degree days (GDD) were used as a measure of heat accumulation (integral of temperature), which in the study area was controlled primarily by elevation (short, cool growing seasons or low GDD for the alpine and longer, warmer growing seasons or a high GDD in the montane and lower foothills). We used annual GDD with base $5^{\circ} \mathrm{C}$ [40], since that is considered the minimum threshold for general plant growth and forage in Alberta [41]. Global solar radiation (sum of shortwave and diffuse radiation) was again measured for each site using a $30 \mathrm{~m}$ DEM and the SHORTWAVC.AML and DIFFUSE.AML ArcInfo scripts from Zimmermann [42]. Influence of landcover (e.g., plant community, competition for soil and light resources, influence on soil chemistry, associated organisms) were based on a remote sensing classification of landcover and a landscape canopy closure model from McDermid et al. [43]. We calculated a correlation matrix (Pearson's) to ensure that model covariates were not highly correlated $(r<0.6)$.

Candidate models included univariate models, simple multivariate models without interactions, and multivariate models with interaction terms believed to be relevant to nutritional dynamics of roots. Candidate models were ranked for support using the Akaike information criterion with small sample size correction $\left(\mathrm{AIC}_{c}\right)$ [44]. Because samples were collected over multiple years, year of collection was used to test for annual variation in nutritional quality. We used the program R [45] to fit mixed-effects generalized linear models (GLMMs) with site used as a random effect to account for multiple samples collected at a site. However, we found no difference between sites (all intercepts were statistically equivalent), which was supported by lower $\mathrm{AIC}_{c}$ ranks $\left(\mathrm{AIC}_{c} w_{i}>2.0\right)$ than models created using fixed-effects 
models (GLMs). Site level variation was likely explained instead by site spatial and temporal variables; therefore, we only report here on fixed-effects models (GLMs) based on $\mathrm{AIC}_{c}$ scores [46]. The most supported model was checked for normality by examining a histogram of residuals followed by a Shapiro-Wilk test. All statistical analyses were conducted in the program R [45].

To interpret spatio-temporal patterns in the nutritional quality of alpine sweetvetch roots, we used our most supported model to predict monthly spatial patterns of crude protein content in roots from 07 May to 07 October. Model predictions were combined with an existing presence/absence model of alpine sweetvetch from Nielsen et al. [39] to limit predictions of protein content to areas where the species was predicted to occur. We did not predict protein content outside of 7 May and 7 October in order to avoid errors associated with extrapolating beyond dates that roots were collected.

\section{Results}

3.1. Phenological Changes. Alpine sweetvetch phenophase varied between mountain and foothills habitats (Table 3 ). Observed phenology in the mountains lagged behind the foothills by 29 days for the preleaf stage, 7 days for the leaf stage, 26 days for the bud stage, 14 days for the flower stage, and 6 days for the seed stage. No lag, however, was observed for the onset of the dormant stage. While there was a lag in the onset of phenological stages between foothills and mountain habitats, the last observations for a particular stage in the mountains and foothills were often close to one another in dates, with the exception of plants in the seed stage lasting up to 17 days later in foothills habitats. This suggests that, despite general lags in the phenological stages of alpine sweetvetch between the two ecosystems, there was local variation potentially due to site level effects.

Crude protein content of alpine sweetvetch roots ranged from 9.0 to $22.4 \%$. Average crude protein content of roots by phenophase were $17.0 \%$ for the preleaf stage $(n=15, \mathrm{SE}=$ $0.51), 17.9 \%$ for the leaf stage $(n=6, \mathrm{SE}=1.50), 15.8 \%$ for the bud stage $(n=14, \mathrm{SE}=0.51), 14.6 \%$ for the flower stage $(n=19, \mathrm{SE}=0.54), 14.8 \%$ for the seed stage $(n=40$, $\mathrm{SE}=0.40)$, and $17.1 \%$ for the dormant stage $(n=18, \mathrm{SE}=$ 18, Table 3, Figure 2). Seasonal differences were significant (ANOVA, $P<0.001$ ) with the preleaf period having higher average crude protein content than both flowering $(P<0.05)$ and seed bearing $(P<0.01)$ stages. Roots of dormant plants were also significantly higher in crude protein content than flowering $(P<0.05)$ and seed bearing $(P<0.05)$ plants.

\subsection{Spatial and Temporal Heterogeneity of Crude Protein} Content in Alpine Sweetvetch Roots. Temporal patterns in the crude protein content of alpine sweetvetch roots were influenced by spatial heterogeneity in annual growing season temperatures and soils with the most supported a priori model including factors for Julian day (nonlinear quadratic response), soil moisture and nutrients (CTI), annual growing degree days $\left(\mathrm{GDD}\right.$ base $\left.5^{\circ} \mathrm{C}\right)$, and a three-way interaction

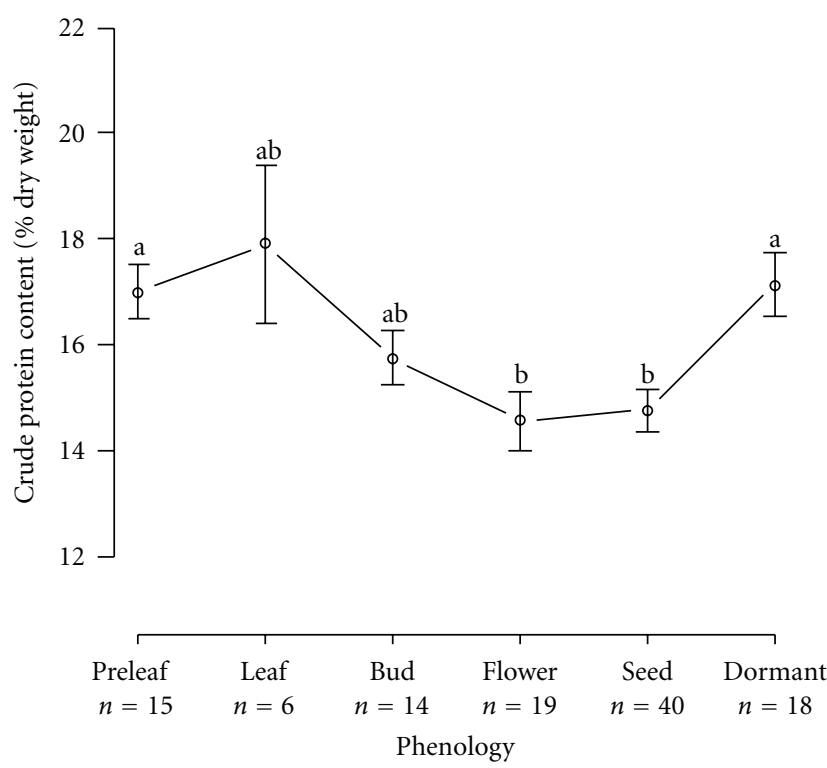

Figure 2: Average crude protein content (\% dry matter basis) of Hedysarum alpinum roots sampled in west-central Alberta, Canada, in different phenological stages. Error bars are 1 standard error above and below the mean. Lower case letters indicate phenophases with significantly different levels of crude protein (i.e., preleaf and flower, preleaf and seed, seed and dormant, flower and dormant).

between Julian day, CTI and GDD (Tables 4 and 5). This suggested that temporal patterns in crude protein content of roots were dependent not only on elevation lags (i.e., temperature) but also, local soil conditions. Specifically, during springtime roots were predicted to have higher protein content in areas with both low soil moisture and annual growing season temperatures as well as areas with high soil moisture and growing season temperatures. Crude protein content in these sites during the spring (21 May) was predicted to be as high as approximately $21 \%$. In contrast, roots growing in areas where annual growing season temperatures were high and soil moisture was low were predicted to have lower protein values $(\sim 16 \%)$. Areas of high soil moisture and low growing season temperatures were predicted to have very low crude protein content at approximately $4 \%$. As spring progressed, spatial patterns in crude protein content of alpine sweetvetch roots were attenuated and equalized across the region by approximately 21 July with increases in crude protein content during late summer and fall following the mirrored response of springtime trends. Thus, during the late summer and fall, areas having high soil moisture and low growing season temperatures as well as low soil moisture and high growing season temperatures were predicted to have higher crude protein content of roots. By 21 September, crude protein content of roots was predicted to be as high as $21 \%$ for optimal sites and as low as $10 \%$ for areas of high moisture and growing season temperatures.

Figure 3 illustrates spatial-temporal predictions of crude protein content for each biweekly period from 7 May to 7 October. A lag in the decline of crude protein at high 
TABLE 3: Range of dates and average percent crude protein content (by dry weight) of alpine sweetvetch (Hedysarum alpinum) roots $(n=112)$ by phenophase for both mountain (elevation $\geq 1700 \mathrm{~m}$ ) and foothills (elevation $<1700 \mathrm{~m}$ ) environments. Phenophase observations and root collection occurred from 2008-2010.

\begin{tabular}{|c|c|c|c|c|c|c|}
\hline Elevation & Preleaf & Leaf & Bud & Flower & Seed & Dormant \\
\hline$\geq 1700 \mathrm{~m}$ & 26 May-17 Jun & $04 \mathrm{Jun}^{\dagger}$ & 30 Jun-06 Jul & 08 Jul-29 Jul & 04 Aug-12 Sep & 17 Sep-13 Oct \\
\hline$<1700 \mathrm{~m}$ & 27 Apr-17 Jun & 28 May-08 Jun & 04 Jun-06 Jul & 24 Jun-30 Jul & $29 \mathrm{Jul}-29 \mathrm{Sep}$ & 17 Sep-17 Oct \\
\hline Crude protein $(\bar{x})$ & $17.0 a^{\S}$ & $17.9 a b$ & $15.8 a b$ & $14.6 b$ & $14.8 b$ & $17.1 a$ \\
\hline$n$ & 15 & 6 & 14 & 19 & 40 & 18 \\
\hline SE & 0.51 & 1.50 & 0.51 & 0.54 & 0.40 & 0.59 \\
\hline
\end{tabular}

${ }^{\dagger}$ There was only one observation made of the leaf phenological stage in mountain habitats.

$\S$ Unique lower case lettering indicates significant differences in crude protein content.

TABLE 4: Hypothesized candidate models, model structure, Akaike Information Criterion with small sample size correction ( AIC $_{c}$ ), difference in $\mathrm{AIC}_{c}$ score from highest ranked candidate model $\left(\Delta \mathrm{AIC}_{c}\right)$, and Akaike weight $\left(w_{i}\right)$ of the top 10 candidate models used to predict crude protein content of alpine sweetvetch (Hedysarum alpinum) in west-central Alberta, Canada. The final model (in bold) was selected based on the highest Akaike weight $\left(w_{i}\right)$ and $\Delta \mathrm{AIC}_{c}>2$.

\begin{tabular}{|c|c|c|c|c|}
\hline Candidate models (hypotheses) & Model structure & $\mathrm{AIC}_{c}$ & $\Delta \mathrm{AIC}_{c}$ & $w_{i}$ \\
\hline Temporal + Soil $*$ Temperature $*$ Temporal & $\mathrm{JDAY}+\mathrm{JDAY} 2+\mathrm{CTI} * \mathrm{GDD} * \mathrm{JDAY}$ & 529.17 & 0 & 0.71 \\
\hline Temporal + Soil $*$ Temperature $*$ Temporal + Year & $\mathrm{JDAY}+\mathrm{JDAY} 2+\mathrm{CTI} * \mathrm{GDD} * \mathrm{JDAY}+\mathrm{YEAR}$ & 532.32 & 3.15 & 0.15 \\
\hline Temporal + Soil & JDAY + JDAY2 + CTI & 535.28 & 6.11 & 0.03 \\
\hline Temporal + Soil + Geology & JDAY + JDAY2 + CTI + GEO & 536.22 & 7.05 & 0.02 \\
\hline Temporal + Soil + Soil $*$ Temporal & $\mathrm{JDAY}+\mathrm{JDAY} 2+\mathrm{CTI}+\mathrm{CTI} * \mathrm{JDAY}$ & 536.60 & 7.43 & 0.02 \\
\hline Temporal + Soil + Temperature & $\mathrm{JDAY}+\mathrm{JDAY} 2+\mathrm{CTI}+\mathrm{GDD}$ & 536.95 & 7.78 & 0.01 \\
\hline Temporal + Soil $*$ Geology $*$ Temporal & $\mathrm{JDAY}+\mathrm{JDAY} 2+\mathrm{CTI} * \mathrm{GEO} * \mathrm{JDAY}$ & 537.75 & 8.58 & 0.01 \\
\hline Temporal + Soil + Temperature $*$ Temporal & $\mathrm{JDAY}+\mathrm{JDAY} 2+\mathrm{CTI}+\mathrm{GDD} * \mathrm{JDAY}$ & 537.88 & 8.71 & 0.01 \\
\hline Temporal + Soil + Geology + Competition & JDAY + JDAY2 + CTI + GEO + LANCOV & 538.43 & 9.26 & 0.01 \\
\hline Temporal + Soil + Geology + Temperature & $\mathrm{JDAY}+\mathrm{JDAY} 2+\mathrm{CTI}+\mathrm{GEO}+\mathrm{GDD}$ & 538.43 & 9.26 & 0.01 \\
\hline
\end{tabular}

TABle 5: Estimated coefficients, standard error (SE), $t$-value, and significance levels $(P)$ of model variables used to predict crude protein content of alpine sweetvetch (Hedysarum alpinum) roots in west-central Alberta, Canada.

\begin{tabular}{lcccc}
\hline Variable & Coef. & SE & $t$-value & $P$ \\
\hline JDAY & -0.702 & 0.124 & -5.64 & $<0.001$ \\
JDAY2 & $0.592^{\dagger}$ & $0.105^{\dagger}$ & 5.65 & $<0.001$ \\
CTI & -12.91 & 3.522 & -3.64 & $<0.001$ \\
GDD & -0.100 & 0.027 & -3.64 & $<0.001$ \\
CTI : GDD & 0.014 & 0.004 & 3.56 & $<0.001$ \\
JDAY : CTI & 0.063 & 0.017 & 3.74 & $<0.001$ \\
JDAY : GDD & $0.503^{\dagger}$ & $0.131^{\dagger}$ & 3.85 & $<0.001$ \\
JDAY : CTI : GDD & $-0.682^{\ddagger}$ & $0.182^{\ddagger}$ & -3.75 & $<0.001$ \\
Intercept & 133.4 & 24.96 & 5.34 & $<0.001$ \\
\hline
\end{tabular}

${ }^{\dagger}$ Estimated coefficients and standard errors are reported at 1,000-times their actual value.

${ }^{\ddagger}$ Estimated coefficients and standard errors are reported at 10,000-times their actual value.

elevations during the first half of the season is apparent. In contrast, during late summer and fall an increase in crude protein content occurred first at lower elevations followed by increases at higher elevations. On 7 May, roots with high protein content ( $>17 \%$ crude protein) were widely predicted for both high and low elevations. By 7 June, protein levels decreased to moderate levels (15.5-17\%) for most low elevation sites, while many higher elevation mountain slopes and valleys retained high protein levels. By 7 July, the protein content of roots at most low elevations decreased to 14$15.5 \%$ crude protein content, while higher protein content root patches could still be found elevated at higher elevations. On 7 August, protein levels began to rise in low elevation river valley patches, and this pattern continued through to 7 October. During this time, the crude protein content of roots at high elevations lagged behind those at low elevations and along the bottoms of river valleys. By 7 September, low elevation valleys had moderate protein levels, while high elevation sites were still in a low protein state. By 7 October, protein levels of roots were predicted to be close to early spring (7 May) levels.

\section{Discussion}

We found that alpine sweetvetch roots had moderate protein content, which was expected given that alpine sweetvetch is a nitrogen fixing legume $[47,48]$. Similar to Hamer and Herrero [29], crude protein content of alpine sweetvetch roots were highest early in the year, declined as phenology advanced to the flowering stage, and increased again to spring levels when dormant. The autumn rebound in crude protein content of roots suggests that a lag in phenology is the main driver of crude protein content in alpine sweetvetch roots. Despite the similarity between our results and Hamer 
May 7

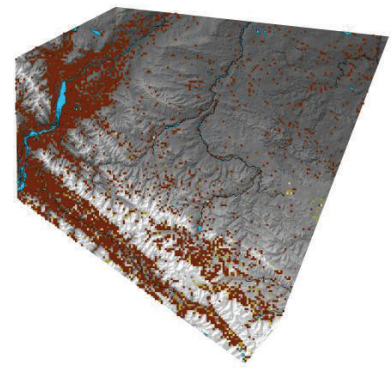

July 7

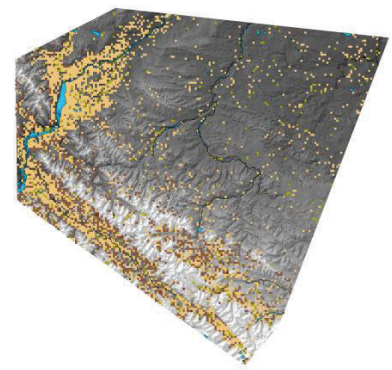

September 7

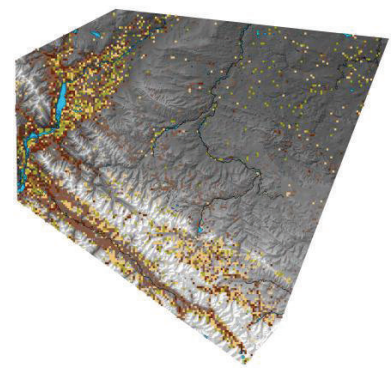

Absent

$<14 \%$ crude protein

$14-15.5 \%$ crude protein
June 7

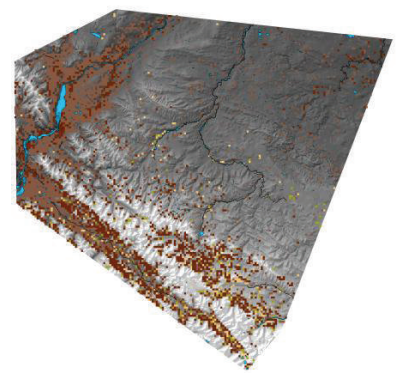

August 7

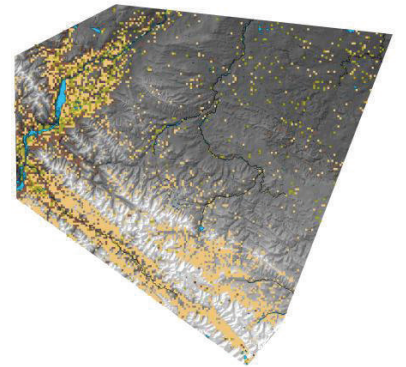

October 7

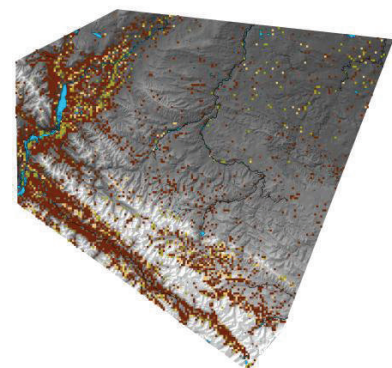

$15.5-17 \%$ crude protein

$>17 \%$ crude protein

Figure 3: Nutritional landscape maps demonstrating "brown tide" patterns in west-central Alberta, Canada, by predicting the percent crude protein content of alpine sweetvetch (Hedysarum alpinum) roots from 7 May to 7 October.

and Herrero [29], alpine sweetvetch roots in west-central Alberta had higher crude protein content, which may be due to differences in laboratory methods (Hamer and Herrero's [29] samples were air-dried at room temperature and were not dry matter corrected). A similar phenological pattern in crude protein content was found for yellow sweetvetch (Hedysarum sulphurescens) roots on the eastern slopes of Banff National Park and the Flathead River valley [29, 30], although crude protein content of yellow sweetvetch roots was noticeably lower than that of alpine sweetvetch. Hamer and Herrero [29] also examined acid detergent fibre content of alpine sweetvetch roots as it related to phenology and found that fibre was inversely related to protein. While total dietary fibre is now considered the most appropriate measure of digestibility for bears [49], we expect that the relationship between fibre, protein, and phenology would remain the same.

We expected spatial heterogeneity in growing season temperature along an elevation gradient to influence the crude protein content of alpine sweetvetch roots. This is because high elevation sites experience later spring greenup and earlier fall frosts than low elevation sites, which results 
in regional differences in plant phenology and gradients of forage quality [50]. Unlike Hamer and Herrero [29], a slope/aspect relationship based on our measures of solar radiation was not supported.

We found not only spatial-temporal lags due to elevation gradients but also local effects on root quality due to variations in soil moisture and nutrients. The effect of soils moisture and nutrients may be due to their influence on the timing of phenology and/or the overall protein content of alpine sweetvetch roots. For instance, the lower protein content of roots in dry low-elevation areas may be due to advanced phenology within the preleaf stage, since spring growth in wet areas may be delayed from excessive water caused by snow melt and/or precipitation. Soil moisture and nutrient composition is also an important factor for nitrogen fixation in legumes such as alpine sweetvetch, where soil moisture is often a limiting factor [51]. This may be the case in wet alpine regions, where spring conditions leave those areas wet or saturated with water due to high snow packs. However, we expect that the extremely low protein value predicted for some springtime wet high-elevation root habitats may be an artefact of sampling, as fewer roots were collected in the subalpine at this time (in fact, many subalpine areas in our study region would likely be snow covered). As well, it is possible that roots with higher spring protein content growing in both dry high-elevation areas and wetter low-elevation areas may experience a combination of temperature and soil moisture conditions that are suitable to nitrogen fixation; our measure (index) of soil moisture has been correlated with soil nutrients including phosphorous [37], which is often a limiting factor in nitrogen fixation [52]. Further examination of the effects of moisture and nutrients on alpine sweetvetch root quality is therefore needed.

Tracking the phenology and nutritional quality of resources over heterogeneous landscapes is an important mechanism by which animals increase diet quality, individual health, and population performance. In this paper, we provide evidence of a "brown wave" or "brown tide" in the nutritional quality alpine sweetvetch root, which suggests that the benefits of resource heterogeneity over space and time extend not only to large herbivores and thus aboveground vegetation but also to omnivores such as grizzly bears and their below-ground resources. While we demonstrate "brown tide" patterns in our study region, we have not explicitly linked this with grizzly bear foraging; however, given previous observations suggesting that grizzly bears track resource phenology along an elevation gradient [29], we expect that such a relationship does, in fact, exist. For this reason, we recommend that future research test the hypothesis that grizzly bears track the phenology and nutritional quality of alpine sweetvetch root.

This work lends to the argument that grizzly bear habitat models should more explicitly consider spatial and temporal heterogeneity in food resources $[25,39]$. In fact, modeling has successfully predicted movement patterns for other wildlife species when animals were assumed to track variations in plant phenology within heterogeneous landscapes $[14,53]$. While we focused on crude protein as a measure of nutritional quality, this approach can also be extended to other nutritional (e.g., carbohydrate, fibre) estimates. As well, energetic estimates (e.g., digestible protein, digestible dry matter, and net digestible energy) could also be used but would require estimates of sweetvetch abundance, density, or biomass which have not yet been developed. Such an approach may be useful in understanding the effects of environmental change on wildlife when combined with factors that regulate populations from the top down [39].

\section{Acknowledgments}

The authors thank Karen Graham, Tracey McKay, Sarah Rovang, and Molly Penzes for field work and sample collection. The authors thank Miladel Casano, Gary Sedgwick, Len Steele, and Will Cornet for help in the nutrition laboratory. Andrew Derocher, David Hik, and three anonymous reviewers provided helpful comments and suggestions that improved this paper. Funding for S. C. P. Coogan was provided by the Foothills Research Institute Grizzly Bear Program, Natural Sciences and Engineering Research Council of Canada (NSERC), the Applied Conservation Ecology laboratory (http://www.ace-lab.org/), and the University of Alberta Faculty of Graduate Studies and Research.

\section{References}

[1] S. J. McNaughton, "Grazing as an optimization process: grassungulate relationships in the Serengeti," American Naturalist, vol. 113, no. 5, pp. 691-703, 1979.

[2] J. Cebrian and J. Lartigue, "Patterns of herbivory and decomposition in aquatic and terrestrial ecosystems," Ecological Monographs, vol. 74, no. 2, pp. 237-259, 2004.

[3] N. Pettorelli, F. Pelletier, A. Von Hardenberg, M. FestaBianchet, and S. D. Côté, "Early onset of vegetation growth vs. rapid green-up: impacts on juvenile mountain ungulates," Ecology, vol. 88, no. 2, pp. 381-390, 2007.

[4] K. R. Searle, N. T. Hobbs, and S. R. Jaronski, "Asynchrony, fragmentation, and scale determine benefits of landscape heterogeneity to mobile herbivores," Oecologia, vol. 163, no. 3, pp. 815-824, 2010.

[5] R. A. Ims, "On the adaptive value of reproductive synchrony as a predator- swamping strategy," American Naturalist, vol. 136, no. 4, pp. 485-498, 1990.

[6] J. M. Fryxell, J. F. Wilmshurst, A. R. E. Sinclair, D. T. Haydon, R. D. Holt, and P. A. Abrams, "Landscape scale, heterogeneity, and the viability of Serengeti grazers," Ecology Letters, vol. 8, no. 3, pp. 328-335, 2005.

[7] I. J. Hobbs and N. T. Gordon, "How does landscape heterogeneity shape population dynamics," in Dynamics of Large Herbivore Populations in Changing Environments: Towards Appropriate Models, N. Owen-Smith, Ed., Wiley-Blackwell, Hoboken, NJ, USA, 2010.

[8] W. J. Mattson, "Herbivory in relation to plant nitrogencontent," Annual Review of Ecology and Systematics, vol. 11, pp. 119-161, 1980.

[9] P. J. Van Soest, Nutritional Ecology of the Ruminant, Cornell University Press, Ithaca, NY, USA, 2nd edition, 1994.

[10] R. H. Drent, B. Ebbinge, and B. Weijand, "Balancing energy budgets of arctic-breeding geese throughout the annual cycle: a progress report," Verhandlungen Ornithologische Gesellschaft Bayern, vol. 23, pp. 239-264, 1978. 
[11] S. van der Graaf, J. Stahl, A. Klimkowska, J. P. Bakker, and R. H. Drent, "Surfing on a green wave-how plant growth drives spring migration in the Barnacle Goose Branta leucopsis," Ardea, vol. 94, no. 3, pp. 567-577, 2006.

[12] O. Duriez, S. Bauer, A. Destin et al., "What decision rules might pink-footed geese use to depart on migration? An individual-based model," Behavioral Ecology, vol. 20, no. 3, pp. 560-569, 2009.

[13] P. P. Marra, C. M. Francis, R. S. Mulvihill, and F. R. Moore, "The influence of climate on the timing and rate of spring bird migration," Oecologia, vol. 142, no. 2, pp. 307-315, 2005.

[14] R. B. Boone, S. J. Thirgood, and J. G. C. Hopcraft, "Serengeti wildebeest migratory patterns modeled from rainfall and new vegetation growth," Ecology, vol. 87, no. 8, pp. 1987-1994, 2006.

[15] G. M. Wang, N. T. Hobbs, R. B. Boone et al., "Spatial and temporal variability modify density dependence in populations of large herbivores," Ecology, vol. 87, no. 1, pp. 95-102, 2006.

[16] G. M. Wang, N. T. Hobbs, S. Twombly et al., "Density dependence in northern ungulates: interactions with predation and resources," Population Ecology, vol. 51, no. 1, pp. 123-132, 2009.

[17] A. Mysterud, "Seasonal migration pattern and home range of roe deer (Capreolus capreolus) in an altitudinal gradient in southern Norway," Journal of Zoology, vol. 247, no. 4, pp. 479486, 1999.

[18] A. Mysterud, R. Langvatn, N. G. Yoccoz, and N. C. Stenseth, "Plant phenology, migration and geographical variation in body weight of a large herbivore: the effect of a variable topography," Journal of Animal Ecology, vol. 70, no. 6, pp. 915923, 2001.

[19] M. Sakuragi, H. Igota, H. Uno et al., "Benefit of migration in a female sika deer population in eastern Hokkaido, Japan," Ecological Research, vol. 18, no. 4, pp. 347-354, 2003.

[20] T. Skogland, "Comparative summer feeding strategies of arctic and alpine Rangifer," Journal of Animal Ecology, vol. 49, no. 1, pp. 81-98, 1980.

[21] M. Iguchi and K. Izawa, "Digging and eating of underground plant-parts by wild Japanese monkeys (Macaca fuscata)," Primates, vol. 31, no. 4, pp. 621-624, 1990.

[22] R. A. Hill and R. I. M. Dunbar, "Climatic determinants of diet and foraging behaviour in baboons," Evolutionary Ecology, vol. 16, no. 6, pp. 579-593, 2002.

[23] J. Herrero, I. Irizar, N. A. Laskurain, A. García-Serrano, and R. García-González, "Fruits and roots: wild boar foods during the cold season in the southwestern Pyrenees," Italian Journal of Zoology, vol. 72, no. 1, pp. 49-52, 2005.

[24] T. A. Fox, I. S. Francis, and E. Bergersen, "Diet and habitat use of svalbard pink-footed geese anser brachyrhynchus during arrival and pre-breeding periods in adventdalen," Ardea, vol. 94, no. 3, pp. 691-699, 2006.

[25] R. H. M. Munro, S. E. Nielsen, M. H. Price, G. B. Stenhouse, and M. S. Boyce, "Seasonal and diel patterns of grizzly bear diet and activity in west-central Alberta," Journal of Mammalogy, vol. 87, no. 6, pp. 1112-1121, 2006.

[26] R. B. Jackson, M. J. Lechowicz, X. Li, and H. A. Mooney, "Phenology, growth, and allocation in global terrestrial productivity," in Terrestrial Global Productivity, J. Roy, B. Saugier, and H. A. Mooney, Eds., Academic Press, San Diego, Calif, USA, 2001.

[27] R. W. Ruess, R. L. Hendrick, A. J. Burton et al., "Coupling fine root dynamics with ecosystem carbon cycling in black spruce forests of interior Alaska," Ecological Monographs, vol. 73, no. 4, pp. 643-662, 2003.

[28] D. F. Steinaker, Belowground and aboveground plant dynamics in a grassland-forest ecotone and experimental monocultures [Ph.D. thesis], University of Regina, Saskatchewan, Canada, 2006.

[29] D. Hamer and S. Herrero, "Grizzly bear food and habitat in the front ranges of Banff National Park, Alberta," in BearsTheir Biology and Management: Proceedings of the Seventh International Conference on Bear Biology and Management, Williamsburg, Va., and Plityice Lakes, Yugoslavia, February and March 1986, P. Zager, Ed., International Association for Bear Research and Management, Washington, DC, USA, 1987.

[30] B. N. McLellan and F. W. Hovey, "The diet of grizzly bears in the Flathead river drainage of southeastern British Columbia," Canadian Journal of Zoology, vol. 73, no. 4, pp. 704-712, 1995.

[31] F. E. Clark, "Internal cycling of 15 nitrogen in a short-grass prairie," Ecology, vol. 58, no. 6, pp. 1322-1332, 1977.

[32] A. C. Holcroft and S. Herrero, "Grizzly bear digging sites for Hedysarum sulphurescens roots in southwestern Alberta," Canadian Journal of Zoology, vol. 62, no. 12, pp. 2571-2575, 1984.

[33] J. D. Beckingham, I. G. W. Corns, and J. H. Archibald, Field Guide to Ecosites of West-Central Alberta, Natural Resources of Canada, Canadian Forest Service, Northwest Region, Northern Forest Centre, Edmonton, AB, Canada, 1996.

[34] C. W. Bater, N. C. Coops, M. A. Wulder et al., "Using digital time-lapse cameras to monitor species-specific understorey and overstorey phenology in support of wildlife habitat assessment," Environmental Monitoring and Assessment, vol. 180, no. 1-4, pp. 1-13, 2011.

[35] W. N. Hamilton, C. W. Langenberg, and M. Price, Bedrock geology of Alberta (GIS data), http://www.ags.gov.ab.ca/ publications/abstracts/DIG_2004_0033.html, 2004.

[36] J. Evans, Compound topographic index, AML script, http://arcscripts.esri.com/details.asp?dbid=11863, 2004.

[37] I. D. Moore, P. E. Gessler, G. A. Nielsen, and G. A. Petersen, "Terrain attributes: estimation methods and scale effectsin," in Modelling Change in Environmental Systems, A. J. Jakeman, M. B. Beck, and M. McAleer, Eds., Wiley, London, UK, 1993.

[38] S. E. Nielsen, R. H. M. Munro, E. L. Bainbridge, G. B. Stenhouse, and M. S. Boyce, "Grizzly bears and forestry: II. Distribution of grizzly bear foods in clearcuts of west-central Alberta, Canada," Forest Ecology and Management, vol. 199, no. 1, pp. 67-82, 2004.

[39] S. E. Nielsen, G. McDermid, G. B. Stenhouse, and M. S. Boyce, "Dynamic wildlife habitat models: seasonal foods and mortality risk predict occupancy-abundance and habitat selection in grizzly bears," Biological Conservation, vol. 143, no. 7, pp. 1623-1634, 2010.

[40] Anon, "Alberta climate prediction model (ACPM) to provide climate predictions for any location in Alberta from its geographic coordinates," Tech. Rep., Alberta Environment/Sustainable Resource Development, Edmonton, AB, Canada, 2003.

[41] S. Chetner and The Agroclimatic Atlas Working Group, Agroclimatic atlas of Alberta, 1971 to 2000, Alberta Agriculture, Food and Rural Development, Edmonton, Alberta, Canada, 2003.

[42] N. E. Zimmermann, Shortwavec.AML and Direct.AML http:// www.wsl.ch/staff/niklaus.zimmermann/progs.html, 2000. 
[43] G. J. McDermid, S. E. Franklin, and E. F. LeDrew, "Remote sensing for large-area habitat mapping," Progress in Physical Geography, vol. 29, no. 4, pp. 449-474, 2005.

[44] K. P. Burnham and D. R. Anderson, Model Selection and Inference: A Practical Information-Theoretic Approach, SpringerVerlag, New York, NY, USA, 1998.

[45] R Core Development Team, R: A language and environment for statistical computing, http://www.R-project.org/, 2009.

[46] M. Hebblewhite and E. Merrill, "Modelling wildlife-human relationships for social species with mixed-effects resource selection models," Journal of Applied Ecology, vol. 45, no. 3, pp. 834-844, 2008.

[47] B. D. Kishinevsky, D. Sen, and G. Yang, "Diversity of rhizobia isolated from various Hedysarum species," Plant and Soil, vol. 186, no. 1, pp. 21-28, 1996.

[48] A. Squartini, P. Struffi, H. Doring et al., "Rhizobium sullae sp. nov. (formerly "Rhizobium hedysari"), the root-nodule microsymbiont of Hedysarum coronarium L.," International Journal of Systematic and Evolutionary Microbiology, vol. 52, no. 4, pp. 1267-1276, 2002.

[49] G. T. Pritchard and C. T. Robbins, "Digestive and metabolic efficiencies of grizzly and black bears," Canadian Journal of Zoology, vol. 68, no. 8, pp. 1645-1651, 1990.

[50] A. Mårell, A. Hofgaard, and K. Danell, "Nutrient dynamics of reindeer forage species along snowmelt gradients at different ecological scales," Basic and Applied Ecology, vol. 7, no. 1, pp. 13-30, 2006.

[51] B. R. Buttery, "Some effects of waterlogging and supply of combined nitrogen on soybean growth," Canadian Journal of Plant Science, vol. 67, no. 1, pp. 69-77, 1987.

[52] L. Lioi and M. Giovannetti, "Variable effectivity of three vesicular-arbuscular mycorrhizal endophytes in Hedysarum coronarium and Medicago sativa," Biology and Fertility of Soils, vol. 4, no. 4, pp. 193-197, 1987.

[53] J. F. Wilmshurst, J. M. Fryxell, B. P. Farm, A. R. E. Sinclair, and C. P. Henschel, "Spatial distribution of Serengeti wildebeest in relation to resources," Canadian Journal of Zoology, vol. 77, no. 8, pp. 1223-1232, 1999. 

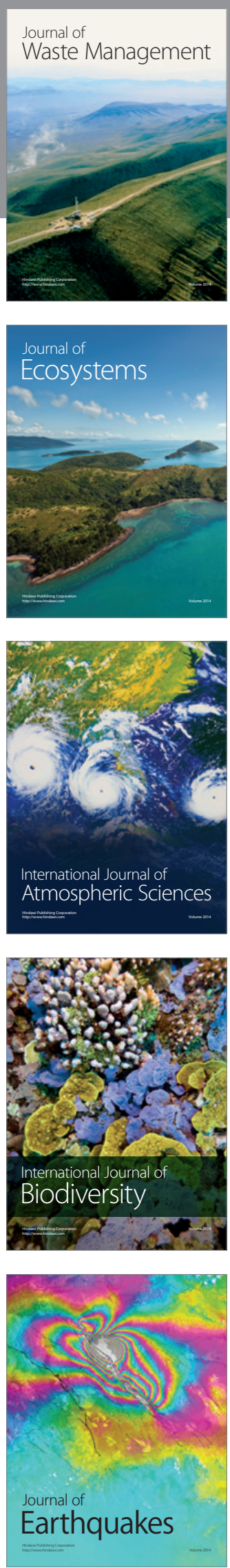
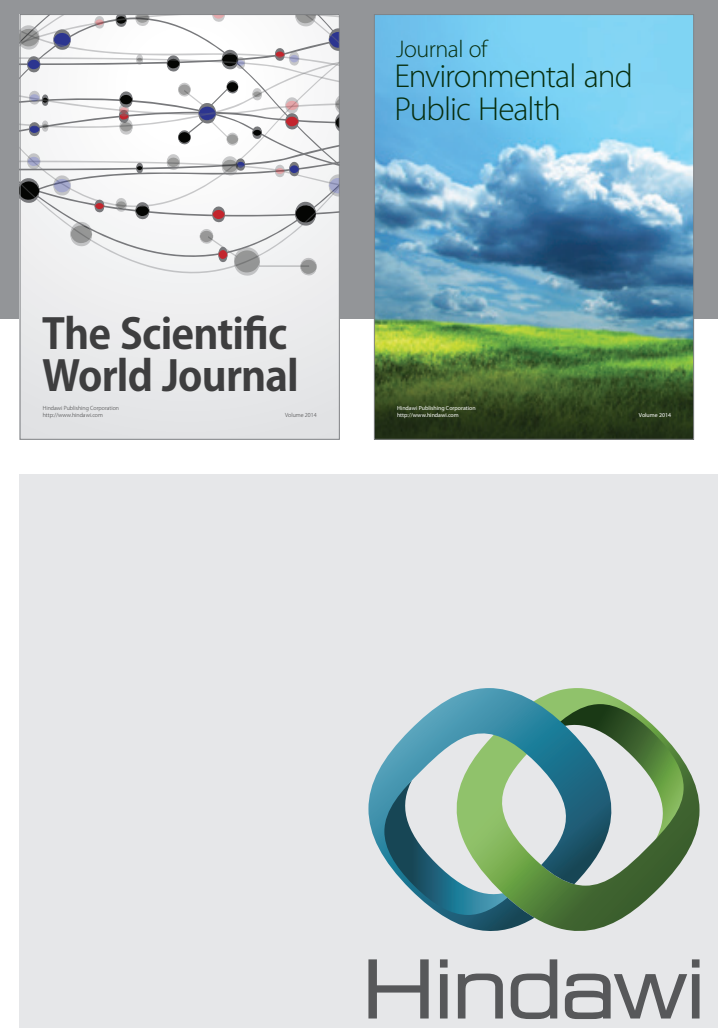

Submit your manuscripts at

http://www.hindawi.com
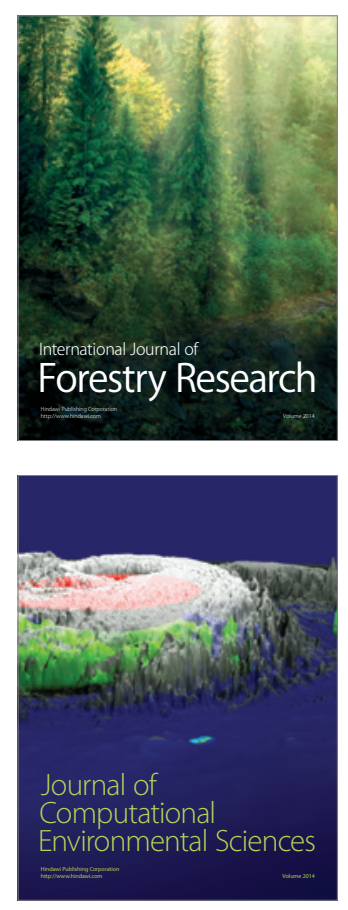
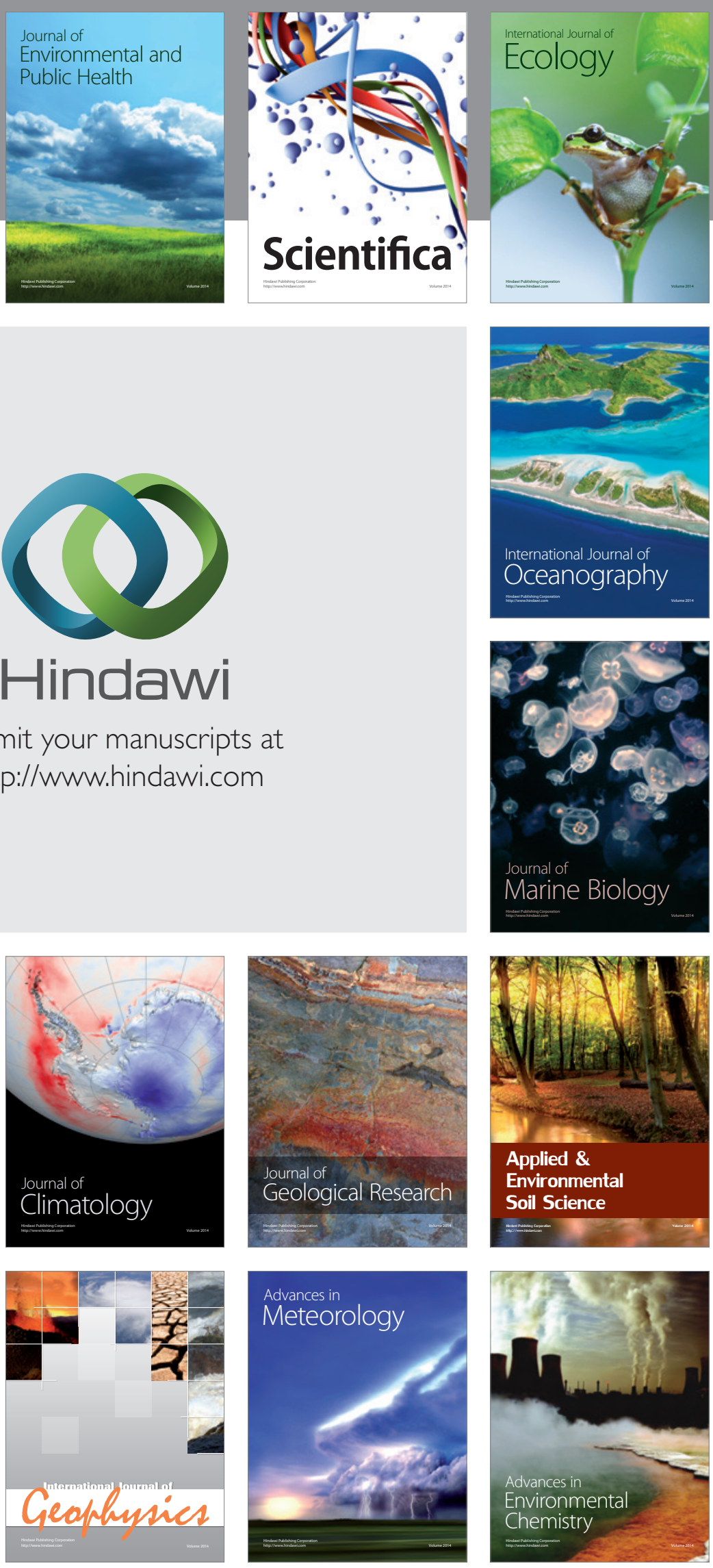